\title{
IDENTIFIKASI TANAMAN BERDASARKAN TIPE FOTOSINTESIS PADA BEBERAPA SPESIES ANGGOTA GENUS FICUS MELALUI PENGAMATAN ANATOMI DAUN
}

\author{
Alif Intan Wibawani dan Ainun Nikmati Laily \\ Jurusan Biologi Fakultas Sains dan Teknologi \\ Universitas Islam Negeri Maulana Malik Ibrahim Malang \\ Email: lailynun@yahoo.com
}

\begin{abstract}
ABSTRAK
Photosynthesis is the process of carbohydrate synthesis of inorganic materials in plants pigmented with the help of sunlight energy. Based on the type of photosynthetic plants are divided into three kinds, namely C3, C4 and CAM. More adaptive C3 plants under conditions of high atmospheric $\mathrm{CO}_{2}$ content and do not have vascular sheath while the $\mathrm{C} 4$ plant more adaptive hot and dry areas, have a vascular sheath cells which are well developed and contain chloroplasts when observed anatomic structures. The purpose of this study was to identify plants by type of photosynthesis in Ficus callosa, F. elastica, F. benjamina, F. fistulosa, F. septica, F. rubiginosa and F. pisocarpa through leaf anatomical observations that cut transversely. The results showed that $F$. elastica and $F$. callosa have well-developed sheath cells surrounding the xylem and phloem, while $F$. benjamina, $F$. fistulosa, F. septica, F. rubiginosa and F. Pisocarpa are not.
\end{abstract}

Keywords: photosynthesis, C3, C4, Ficus, leaf anatomy

\section{PENDAHULUAN}

Fotosintesis adalah proses pembuatan energi atau zat makanan yang berlangsung atas peran cahaya matahari dengan menggunakan zat hara, karbon dioksida, dan air. Makhluk hidup yang mampu melakukan fotosintesis adalah tumbuhan, alga, dan beberapa jenis bakteri. Fotosintesis penting bagi kehidupan di bumi karena hampir semua makhluk hidup bergantung pada energi yang dihasilkan oleh proses fotosintesis (Syarif, 2009).

Berdasarkan tipenya, fotosintesis dibedakan menjadi 3 macam yaitu $\mathrm{C} 3, \mathrm{C} 4$ dan CAM. Tanaman C3 dan $\mathrm{C} 4$ dibedakan oleh cara mengikat $\mathrm{CO}_{2}$ dari atmosfir dan produk awal yang dihasilkan dari proses asimilasi. Pada tanaman $\mathrm{C} 3$, Rubisco menyatukan $\mathrm{CO}_{2}$ dengan $R u B P(R u B P$ merupakan substrat untuk pembentukan karbohidrat dalam proses fotosintesis) dalam proses awal asimilasi, juga dapat mengikat $\mathrm{O}_{2}$ pada saat yang bersamaan untuk proses fotorespirasi. Jika konsentrasi $\mathrm{CO}_{2}$ di atmosfir ditingkatkan, hasil dari kompetisi antara $\mathrm{CO}_{2}$ dan $\mathrm{O}_{2}$ akan lebih menguntungkan $\mathrm{CO}_{2}$, sehingga fotorespirasi terhambat dan asimilasi akan bertambah besar (Fahn,1982).

Pada tanaman $\mathrm{C} 4, \mathrm{CO}_{2}$ diikat oleh PEP (enzim pengikat $\mathrm{CO}_{2}$ pada tanaman $\mathrm{C} 4$ ) yang tidak dapat mengikat $\mathrm{O}_{2}$ sehingga tidak terjadi kompetisi antara $\mathrm{CO}_{2}$ dan $\mathrm{O}_{2}$. Lokasi terjadinya asosiasi awal ini adalah di sel-sel mesofil (sekelompok sel-sel yang mempunyai klorofil yang terletak di bawah sel-sel epidermis daun). $\mathrm{CO}_{2}$ yang sudah terikat oleh PEP kemudian ditransfer ke sel-sel bundle sheath (sekelompok sel-sel di sekitar xylem dan floem) dimana kemudian pengikatan dengan $R u B P$ terjadi. Karena tingginya konsentasi $\mathrm{CO}_{2}$ pada sel-sel seludang pembuluh ini, maka $\mathrm{O}_{2}$ tidak mendapat kesempatan untuk bereaksi dengan $R u B P$, sehingga fotorespirasi sangat kecil, PEP mempunyai daya ikat yang tinggi terhadap $\mathrm{CO}_{2}$, sehingga reaksi fotosintesis terhadap $\mathrm{CO}_{2}$ di bawah $100 \mathrm{~m} \mathrm{~mol} \mathrm{~m}^{-2} \mathrm{~s}^{-1}$ sangat tinggi, laju asimilasi tanaman $\mathrm{C} 4$ hanya bertambah sedikit dengan meningkatnya $\mathrm{CO}_{2}$. Dengan meningkatnya $\mathrm{CO}_{2}$ di atmosfir, tanaman $\mathrm{C} 3$ akan lebih beruntung dari tanaman $\mathrm{C} 4$ dalam hal pemanfaatan $\mathrm{CO}_{2}$ yang berlebihan (Brotowidjoyo, 1989).

Titik kompensasi $\mathrm{CO}_{2}$ pada tanaman golongan $\mathrm{C} 3$ lebih tinggi daripada tanaman golongan C4. Akibatnya, kapasitas hasil bersih fotosintesisnya jauh lebih rendah. Pengaruh intensitas cahaya yang diterima terhadap hasil bersih fotosintesis, diantara kedua golongan tanaman juga terdapat perbedaan. Tanaman golongan C3 mempunyai kapasitas fotosintesis 
yang lebih rendah, karena telah mencapai laju maksimum fotosintesis bersih yang lebih rendah daripada tanaman golongan C4. Tanaman-tanaman yang mempunyai kapasitas fotosintesis yang lebih tinggi (golongan C4) hasil bersih fotosintesisnya akan terus meningkat sampai intensitas cahaya yang cukup tinggi. Laju fotosintesis C3 dan C4 akan sama apabila intensitas cahaya dalam keadaan rendah, misalnya pada cuaca berawan. Oleh karena itu, kalau mendapatkan intensitas cahaya rendah, tanaman-tanaman dari golongan C4 pun rendah hasilnya (Fahn,1982).

Tanaman golongan $\mathrm{C} 4$ dapat tumbuh lebih baik daripada tanaman golongan C3 dalam keadaan lingkungan yang kurang baik. Hal ini dapat terlihat bahwa di daerah kering umumnya tanaman-tanaman dari golongan $\mathrm{C} 4$ dapat hidup lebih baik dibanding dengan tanaman $\mathrm{C} 3$. Pengaruh $\mathrm{O}_{2}$ terhadap hasil bersih fotosintesis disebut Warburg effect bahwa rendahnya fotosintesis bersih pada tanaman-tanaman golongan $\mathrm{C} 3$ tidak lain merupakan peristiwa kompetisi antara $\mathrm{O}_{2}$ dan $\mathrm{CO}_{2}$ terhadap bekerjanya enzim fotosintesis karboksilase yang sangat penting yaitu ribulosa bifosfat karboksilase $(R u B P$ karboksilase $=$ Rubisco $)$. Enzim tersebut bukan hanya merupakan enzim karboksilase tetapi juga mengkatalisis reaksi oksidasi dari Ribulosa bifosfat (RuBP) menjadi senyawa PGA (asam fosfogliserat) dan asam fosfoglikolat (Syarif, 2009).

Ficus merupakan genus tumbuh-tumbuhan yang secara alamiah tumbuh di daerah tropis dengan sejumlah spesies hidup di zona ugahari. Terdiri dari sekitar 850 spesies, jenis-jenis Ficus dapat berupa pohon kayu, semak, tumbuhan menjalar dan epifit serta hemi-epifit dalam familia Moraceae. Ciri-ciri yang paling menonjol dari Ficus adalah keluarnya getah berwarna putih bila batang atau cabangnya dipotong. Bentuk dan karakter daun Ficus bermacam-macam, antara lain daun dengan tulang daun warna putih, bundar serta mengkilap, daun tebal, terasa kasar seperti ampelas bila diraba, dan sebagainya. Pada pengamatan anatomi Ficus terdiri atas epidermis, mesofil, stomata, jaringan tiang, jaringan bunga karang, berkas pembuluh, ada yang memiliki seludang pembuluh meskipun sebagian besar tidak, serta memiliki lapisan kutikula (Suradinata, 1998).

Secara anatomi pada irisan melintang daun terlihat beberapa sistem jaringan pada daun, yaitu jaringan epidermis, mesofil atau parenkim dan jaringan pembuluh. Epidermis pada daun pada umumnya terdiri atas selapis sel. Kecuali pada Ficus sp. memiliki epidermis ganda. Jaringan epidermis ini terdiri atas epidermis atas (epidermis adaksial) dan epidermis bawah (epidermis abaksial). Pada epidermis atas terdapat kutikula. Kutikula ini berfungsi sebagai pencegah keringnya jaringan di bawah epidermis dan melindungi jaringan yang berada dibawahnya dari gangguan mekanis. Pada epidermis atas tidak terdapat klorofil, sedangkan pada bagian epidermis bawah terdapat stomata (Suradinata, 1998).

Tujuan penelitian ini adalah untuk mengidentifikasi tanaman berdasarkan tipe fotosintesis pada $F$. callosa, $F$. elastica, $F$. benjamina, $F$. fistulosa, $F$. septica, $F$. rubiginosa, dan $F$. pisocarpa.

\section{METODE PENELITIAN}

Penelitian dilaksanakan di Laboratorium Optik Jurusan Biologi Fakultas Sains dan Teknologi Universitas Islam Negeri Maulana Malik Ibrahim Malang pada bulan Desember 2014.

Bahan-bahan yang digunakan dalam penelitian ini adalah daun $F$. callosa, $F$. elastica, $F$. benjamina, $F$. fistulosa, $F$. septica, $F$. rubiginosa dan $F$. picarpa yang diambil dari tempat berbeda. Alat-alat yang digunakan adalah mikroskop, pisau atau cutter, kaca benda, dan kaca penutup.

Daun $F$. callosa, $F$. elastica, $F$. benjamina, $F$. fistulosa, $F$. septica, $F$. rubiginosa dan $F$. picarpa diiris secara melintang untuk mengetahui struktur anatomi daun tersebut secara lengkap dengan perbesaraan $40 \mathrm{X}$ sehingga dapat terlihat penampang melintang dari ketujuh daun tersebut kemudian digunakan untuk mengidentifikasi tipe fotosintesis yaitu tipe $\mathrm{C} 3$, $\mathrm{C} 4$, atau CAM. Perbedaan antara tumbuhan C3 dengan $\mathrm{C} 4$ berdasarkan pengamatan anatomi dapat diketahui dengan keberadaan seludang pembuluh ketika dibuat sayatan secara melintang. Apabila tumbuhan tersebut memiliki seludang pembuluh digolongkan tumbuhan memiliki fotosintesis $\mathrm{C} 4$ dan apabila tidak memiliki seludang pembuluh digolongkan memiliki tipe fotosintesis C3. Untuk tanaman CAM biasanya terdapat pada tanaman yang sukulen atau mengandung banyak air. Anatomi daun pada tanaman $\mathrm{C} 4$ dan $\mathrm{C} 3$ terdapat perbedaan yang unik, berkaitan dengan mekanisme fotosintesisnya. Pada tanaman C4 
terdapat dua jenis sel fotosintetik yang berbeda yaitu sel seludang berkas pembuluh dan sel mesofil (Dwijoseputro, 1998).

\section{HASIL DAN PEMBAHASAN}

Berdasarkan hasil pengamatan yang telah dilakukan terhadap $F$. callosa, $F$. elastica, $F$. benjamina, $F$. fistulosa, $F$. septica, $F$. rubiginosa dan $F$. picarpa. Ada diantara ketujuh spesies ini memiliki seludang pembuluh dan ada yang tidak memiliki seludang pembuluh.

Tumbuhan yang memiliki seludang pembuluh adalah $F$. callosa dan $F$. elastica yang mana daun yang diiris melintang terlihat bagian bagiannya seperti epidermis atas dan bawah, jaringan tiang (parenkim palisade), hipodermis, stomata, mesofil, jaringan bunga karang (parenkim spongiosa), adanya berkas pembuluh (xylem dan floem) yang dilengkapi dengan seludang pembuluh disekelilingnya. Sedangkan pada tumbuhan $F$. septica, $F$. rubiginosa, $F$. pisocarpa, dan $F$. benjamina tidak terdapat adanya seludang pembuluh yang berasa disekeliling berkas pembuluh yaitu xylem dan floem. Irisan melintang daun tersebut terdiri atas beberapa bagian yaitu epidermis atas dan bawah, berkas pembuluh yaitu xylem dan floem, stomata, mesofil, jaringan tiang (parenkim palisade) dan jaringan bunga karang (parenkim sponsgiosa). Pada $F$. benjamina terdapat litosit dan sistolit. Pada F. pisocarpa terdapat rongga udara yang terletak diantara epidermis dan jaringan tiang (parenkim palisade) yang bentuknya hampir sama dengan seludang pembuluh namun itu bukan seludang pembuluh karena di dalamnya tidak terdapat berkas pembuluh, hanya rongga udara kosong.

Tabel 1. Hasil Pengamatan Irisan Melintang Daun Genus Ficus

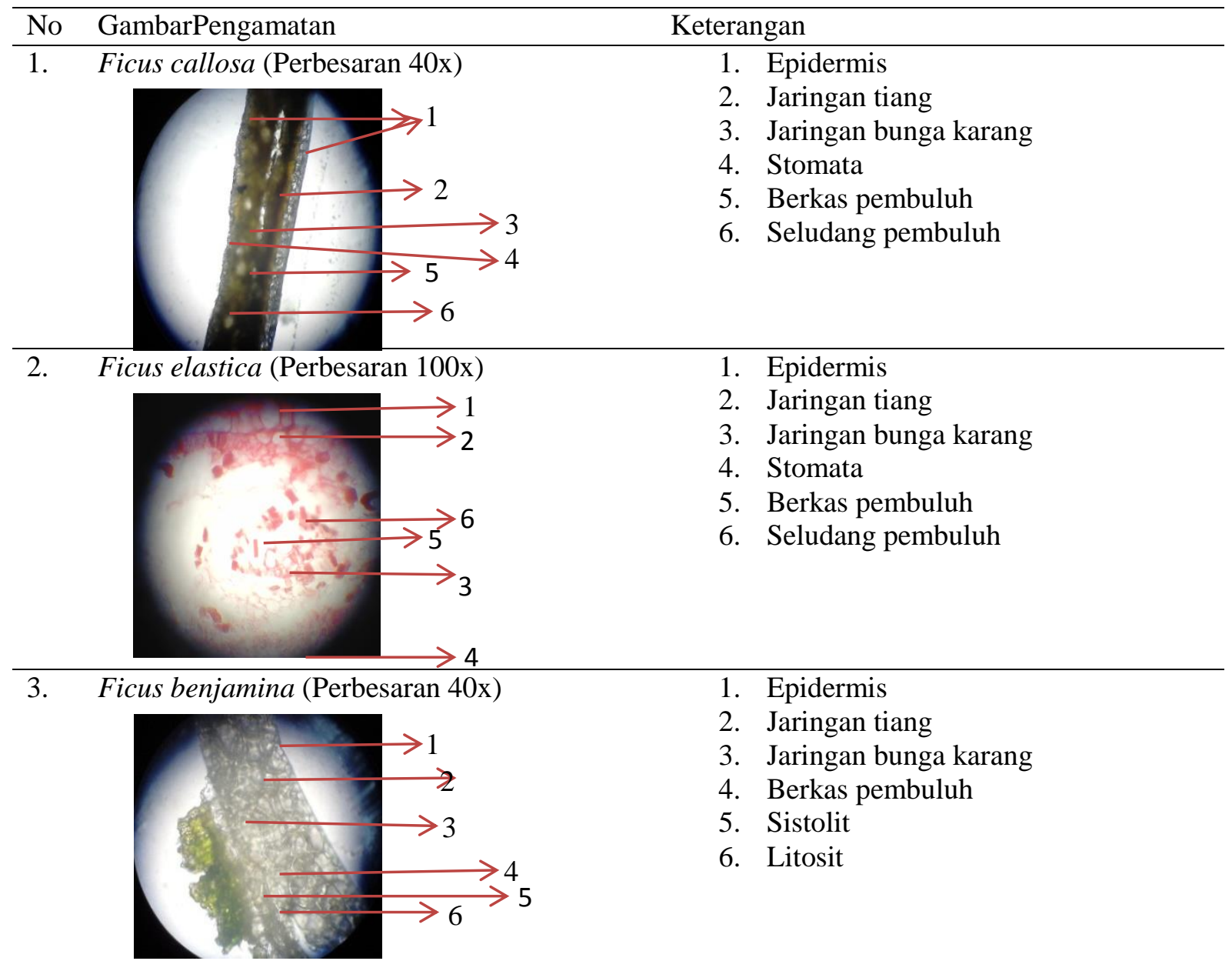


4. Ficus fistulosa (Perbesaran 40x)

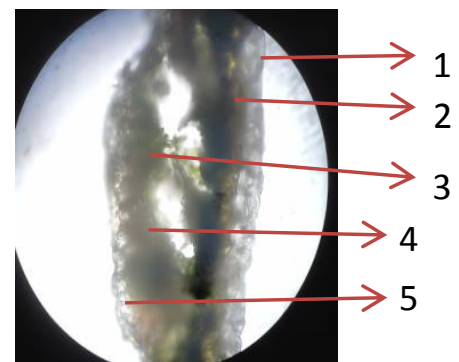

5. Ficus septica (Perbesaran 100x)

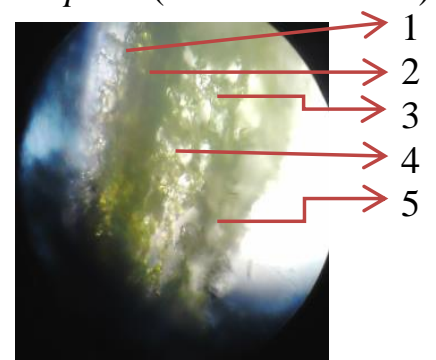

6. Ficus rubiginosa (Perbesaran 40x)

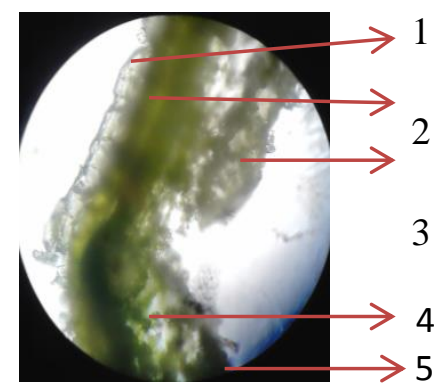

7. $\quad$ Ficus pisocarpa $($ Perbesaran 40x)

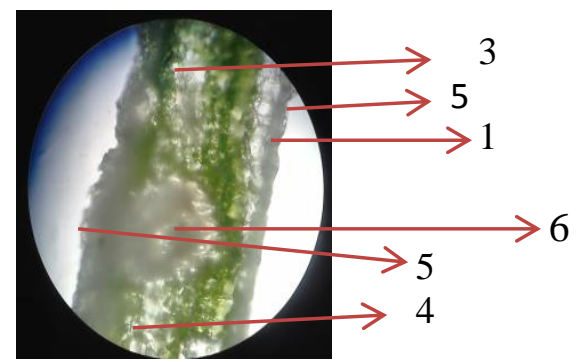

1. Epidermis

2. Jaringan tiang

3. Parenkim sponsgiosa

4. Berkas pembuluh

5. Stomata
1. Epidermis

2. Jaringan tiang

3. Parenkim sponsgiosa

4. Berkas pembuluh

5. Stomata
1. Epidermis

2. Jaringan tiang

3. Parenkim sponsgiosa

4. Berkas pembuluh

5. Stomata
Hasil pengamatan menunjukkan bahwa $F$. elastica dan $F$. callosa memiliki seludang pembuluh yang mengelilingi xylem dan floem. Ciri ini dimiliki oleh tumbuhan $\mathrm{C} 4$ yang lebih adaptif didaerah panas dan kering sedangkan pada $F$. septica, $F$. rubiginosa, $F$. pisocarpa dan $F$. benjamina tidak ditemukan.

Pada tumbuhan dikotil, daun terdiri atas tangkai (petiola) dan helai daun (lamina), sedangkan daun monokotil tidak bertangkai, langsung melekat pada batang. Jaringan penyusun daun meliputi epidermis, mesofil (parenkim), dan berkas pembuluh (Campbell, dkk 2003).
Epidermis terdapat di permukaan atas dan di permukaan bawah daun. Umumnya terdiri dari selapis sel seperti pada daun Ficus sp. dan Piper (sirih). Sel-selnya berdinding tebal dan pada bagian yang menghadap keluar dilapisi oleh kutikula untuk membatasi penguapan air yang terlalu besar, kadang-kadang pada daun juga dijumpai lapisan lilin atau rambut. Pada epidermis terdapat stomata (mulut daun), yaitu celah yang dibatasi oleh sel penutup. Lapisan epidermis atas berfungsi melindungi bagian di bawahnya. Stomata sebagai tempat keluar masuknya udara dan dengan menghubungkan ruang-ruang antar sel di dalam jaringan 
parenkim dengan atmosfer. Pada tumbuhan darat, stomata terletak di permukaan bawah daun (Lakitan, 1996) .

Mesofil merupakan jaringan dasar yang tersusun atas jaringan palisade (jaringan tiang) dan jaringan spons (bunga karang) (Suradinata, 1998). Pada tumbuhan dikotil, di bawah epidermis terdapat sel-sel parenkim. Sel-sel parenkim tersebut membentuk jaringan parenkim palisade dan jaringan sponss. Jaringan parenkim palisade merupakan jaringan parenkim pada daun yang memiliki banyak kloroplas sehingga pada jaringan ini terjadi proses fotosintesis. Sel pada parenkim palisade tersusun sangat rapat. Jaringan spons pada tumbuhan dikotil merupakan jaringan yang di dalamnya terdapat pembuluh pengangkut. Pada jaringan ini terdapat kloroplas, namun jumlahnya lebih sedikit dibandingkan dengan kloroplas dalam parenkim palisade (Fahn, 1982).

\section{KESIMPULAN}

Dari keseluruhan 7 spesies anggota Genus Ficus dalam penelitian, dua di antaranya $F$. elastica dan $F$. callosa memiliki seludang pembuluh yang mengelilingi xylem dan floem, dengan demikian dapat dikategorikan termasuk dalam tanaman C4. Pada lima spesies berikutnya yaitu $F$. benjamina, $F$. fistulosa, $F$. septica, $F$. rubiginosa dan $F$. pisocarpa tidak ditemukan adanya seludang pembuluh sehingga perlu dipastikan ciri lain yang mendukung kategori tanaman $\mathrm{C} 3$ atau $\mathrm{C} 4$.

\section{DAFTAR PUSTAKA}

Brotowidjoyo. 1989. Botani Dasar. Jakarta : Erlangga

Campbell, , Reece. dan Mitchell. 2003. Biologi Jilid 2. Jakarta. Erlangga

Fahn, A. 1982. Plant Anatomy. Fourth Edition. Oxford : Pergamon Press.

Lakitan, B. 1996. Fisiologi Pertumbuhan dan Perkembangan Tanaman. Jakarta : Rajawali Pers

Syarif, 2009. Struktur dan Fungsi Jaringan Tumbuhan. Bandung : Pusat Pengembangan dan Pemberdayaan Pendidikan

Suradinata, 1998. Struktur Tumbuhan. Bandung : Angkasa 